\title{
How Do We Interact Online? An Approach to Researching Multidimensionality of Online Communication ${ }^{1}$
}

\author{
Dalibor Petrović, ${ }^{2}$ \\ Department of Social Sciences, Faculty of Transport and Traffic \\ Engineering, University of Belgrade
}

\section{Miloš Bešić}

Faculty of Political Sciences, University of Belgrade

\author{
Marijana Petrović \\ Department of Management, Organization and Economy, Faculty of \\ Transport and Traffic Engineering, University of Belgrade
}

\begin{abstract}
If different dimensions of online interaction are neglected and/or unknowingly combined in a research study there is a risk of misleading results due to compensatory effect. With respect to the multidimensionality of online interaction, two substantially different types of online communication are defined - procreative and transmissional. The procreative online communication is understood as a person's tendency to use the internet as a space for social interaction, which essentially differs from using the internet transmissionally, as a peer-to-peer communication channel between people who are familiar with one another. The aim of this paper is to explore more deeply the procreative dimensions of online communication. Based on our conceptual framework, we defined three procreativity dimensions and developed an Online Procreativity Scale (OPS) to measure them. The OPS has been validated through EFA and CFA and the three-dimensional structure has been confirmed. Using the OLS regression analyses we found that gender and psychological characteristics and social network sites (SNS) use have diverse influence depending on the procreativity dimension under observation. Gender, city size, share of unfamiliar SNS friends and loneliness predicted willingness to interact with strangers, while the time spent on SNS predicted only the tendency to participate in public online interaction.
\end{abstract}

Key words: online communication dimensions, procreativity, Online Procreativity Scale, predictors

1 This paper is a part of the project TR36022 funded by the Ministry of Education, Science and Technological Development of the Republic of Serbia.

2 d.petrovic@sf.bg.ac.rs 


\section{Introduction}

There is a broad discussion among theorists and researchers whether online interaction is motivated by the need to compensate for social and psychological deficiency or, conversely, by the need to enrich the existing communication channels. We suggest that these two perspectives are not necessarily mutually exclusive if we take into account that online communication is a multidimensional phenomenon. The mere fact that someone likes to chat reveals almost nothing about the way s/he interacts online. In other words, chatting with best friends via instant messenger (IM) should be viewed as a different aspect of online interaction compared to chatting with strangers in a chat room or via Twitter, in at least four respects: interaction (non-anonymous vs. anonymous), participants (familiar vs. strangers), privacy (private vs. public) and aim (maintaining vs. forming relationships). Although, there are some authors who underline these differences (Valkenburg \& Peter, 2007a, 2007b) or at least acknowledge them (Bargh \& McKenna, 2004; van den Eijnden et al., 2008; Van Zalk, et al., 2011; Zhao, 2006, Kim et al., 2007), the majority disregards the multidimensionality of online interaction (Chan, 2011; Chang \& Zhu 2011; Chung \& Lee, 2012; Correa, Hinsley \& Homero, 2010; Desjarlais \& Willoughby, 2010; Kang, 2007; Lien \& Cao 2014; Ong, Chang \& Wang, 2011; Park, Wang, Jackson \& Zhang, 2011; Pollet, Roberts \& Dunbar 2011; Stepanikova, Norman \& Xiaobin, 2010; Weidman et al., 2012).

In order to overcome this problem, we introduced an approach to reveal different types and dimensions of online communication. Thus, we aim at eliminating the risk of finding misleading null-effects when different dimensions of online communication are unknowingly combined during the research. Valkenburg and Peter (2007a, 2007b) indicated this problem and the need to acknowledge different roles of various communication technologies. They found that the time spent using instant messengers (IM) among teenagers was positively related to the time spent with existing friends. However, the positive effects of the study held only for the time spent with IM and not for the time spent with chat in a public chat room because IM and chat had very different functions for adolescents - the majority of adolescents used IM to talk with their existing friends while adolescents primarily chatted with strangers in chat rooms.

Although we follow the idea of Valkenburg and Peter, our approach to researching online interaction goes beyond mere identification of communication technology in use. In our view, it is not heuristically useful to research online communication solely based on employed communication platforms, since their purpose changes over time. For instance, IMs were once used to make new contacts (Leung, 2001; Ma \& Leung, 2006) while today they mainly serve to maintain existing relationships (Dimmick, et al. 
2011; Ramirez \& Broneck, 2009). Also, in the past, chat rooms were the main place for hanging out and meeting new people (McCown et al., 200; Parks \& Floyd, 1996; Peris et al., 2002), while today this function has been gradually overtaken by SNS (Hogan, Dutton \& Li, 2011; Petrović, 2012).

Hence, our study contributes both theoretically and empirically to overcoming the existing neglect of the multidimensionality of online interaction. We depicted two substantially different types of online communication - transmissional and procreative. Also, we further analyzed the dimensions of online procreativity and constructed a scale for measuring it. The dimensions defined in our study are not necessarily determined by a certain medium of communication, but rather by the scope of communication it provides. In other words, the same medium can contribute to different dimensions of online communication and vice versa, as one dimension can be manifested through various media.

\section{Transmissional and procreative online communication}

In order to understand the multidimensionality of online interaction we suggest an approach that recognizes the different dimensions of communication. This approach is inspired by the Carey's (2002) concept of transmission and ritual models of communication as well as Craig's (1999; 2007) field theory of communication. In short, these authors posit that communication can be regarded as a transmission of signals or messages over a distance for the purpose of control (Carey, 2002). However, communication can also be seen as a ritual (Carey, 2002) or a constitutive (Craig, 2007) act, wherein communication is the primary social process through which our meaningful common world is constructed. Building on Carey`s and Craig's concepts, we suggest that online communication should be viewed with reference to two basic and fundamentally different communication types: transmissional and procreative (Petrović, 2009; 2013).

The transmissional type of online communication is based on intentional, private, peer-to-peer communication between familiar people, where the internet serves as a channel for communicating, like the telegraph or telephone. In that case, the internet represents interpersonal medium (Dimmick, Feaster \& Ramirez, 2011; Lüders, 2008; Petric, Petrovcic \& Vehovar, 2011; Petrović, 2013) whose principal function is the transmission of communication over a distance. To make it simple, used transmissionally the internet is just another tool employed for the purpose of maintaining personal network of relationships (Bargh \&McKenna, 2004; Boase, 2008; Grinter \& Palen, 2002; Licoppe \& Smoreda 2005; van den Eijnden, et al., 2008). Therefore, basic features of the transmissional type of online communication are private communication and mutual familiarity of communication peers. 
A completely different type of interaction occurs when communicators target cyberspace, i.e. a virtual place for interaction made available by networks of interconnected computers (Ploug, 2009). In that case, the internet becomes a virtual third place (Oldenburg \& Brissett, 1982; Soukup, 2006) with a markedly procreative function. Unlike transmissional communication, interaction in cyberspace is not encapsulated in peer-to-peer channels or limited only to familiar people. Hence, anonymity and/or possibility to socialize (with someone unknown or already familiar) in cyberspace are constitutive elements of online procreativity. In order to be procreative, online communication has to produce something, either new social contacts or renewed ties with familiar people. The main social function of online procreativity is renewal of sociability, where sociability is interpreted as a tendency to affiliate with others and to prefer being with others to remaining alone (Cheek \& Buss, 1981).

Therefore, basic features of the procreative type of online communication are private or public interaction between strangers or familiar people.

Now, using two basic criteria (private/public communication and presence/absence of familiarity) we can distinguish the following dimensions of online communication (Figure 1): Private communication between familiar people (PvCBF), Private communication between strangers (PvCBS), Public communication between strangers (PbCBS) and Public communication between familiar people ( $\mathrm{PbCBF})$.

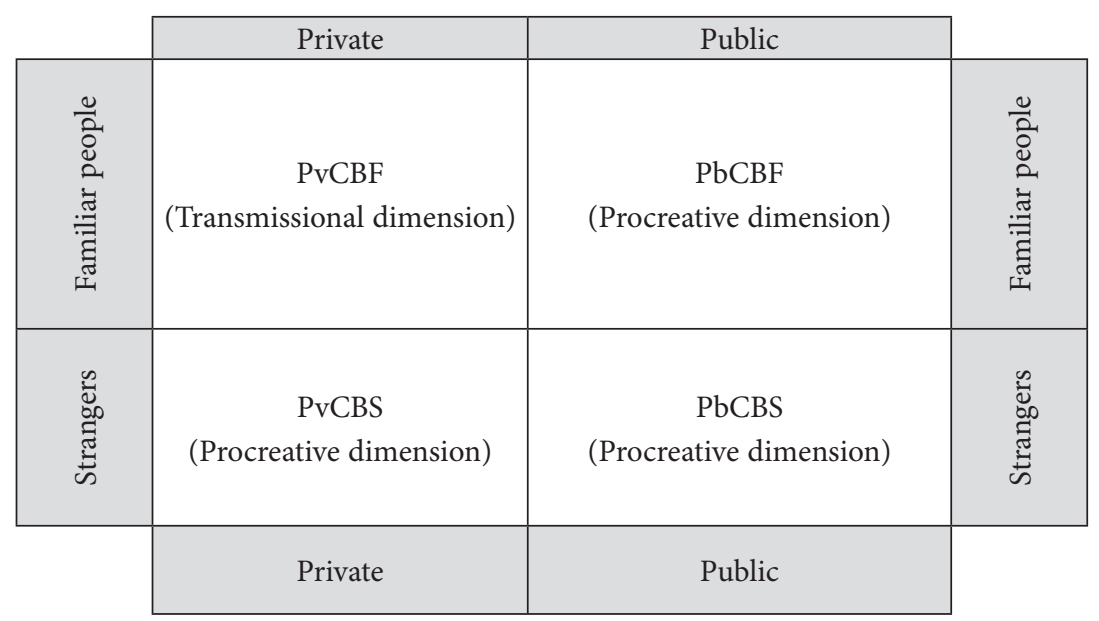

Figure 1: Four dimensions of online communication

According to our theoretical framework, we argue that the PvCBF dimension fits into the transmissional type of online communication while the $\mathrm{Pv}$ $\mathrm{CBS}, \mathrm{PbCBS}$ and $\mathrm{PbCBF}$ dimensions belong to the procreative type of online communication (Figure 2). 


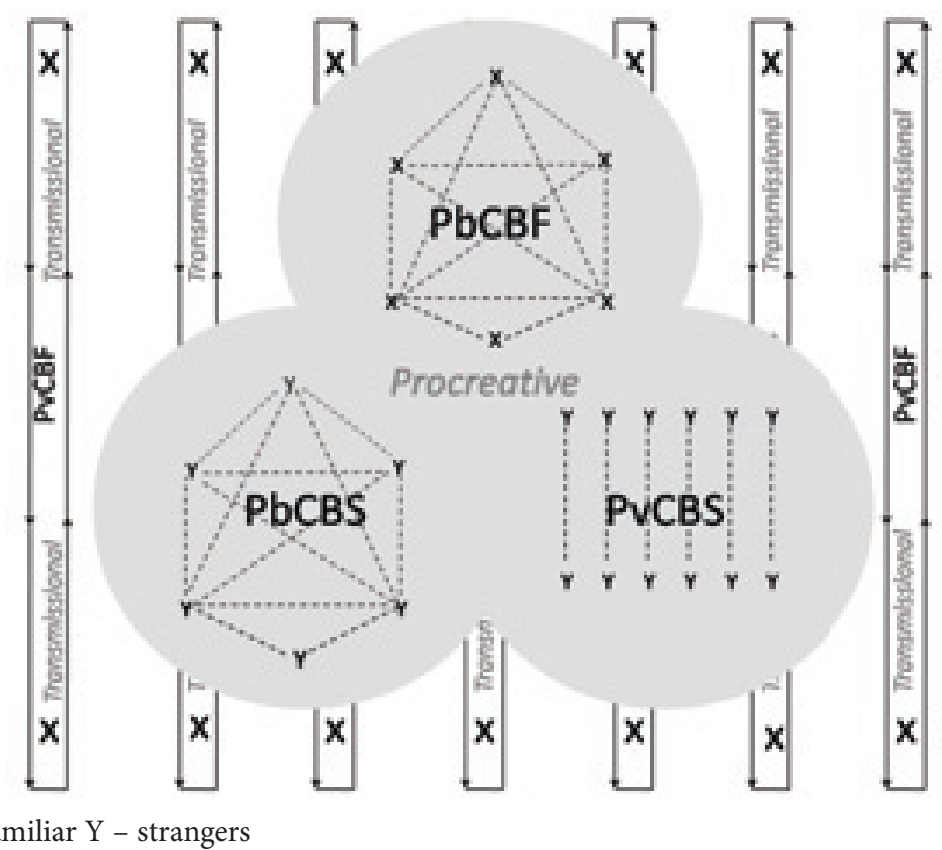

Figure 2: Scheme depiction of four online communication dimensions

\section{Research goals and hypothesis}

Since the transmissional type of online communication has been extensively elaborated through interpersonal media theories (Dimmick, Feaster \& Ramirez, 2011; Hwang, 2011; Lüders, 2008; Petric, Petrovcic \& Vehovar, 2011; Petrović, 2013), the aim of our study was to analyze more deeply the procreative use of the internet. We strived to empirically verify different dimensions of online procreativity and to develop an appropriate measuring instrument.

There have been numerous attempts to study online interaction in cyber space but many of them did not pay much attention to all dimensions of online communication or they only targeted specific communication platforms like Facebook, IM, chat rooms and so forth. A frequent critical inadequacy of some authors was that they did not differentiate between modes of online interaction that cannot be combined within the same communicational type. For example, Johnson and Kulpa (2007) proposed a three-dimensional Brief Test of Online Behavior, where one of the dimensions, to wit, sociability, was measured using five statements. However, two of those statements ("I meet new people online" and "The Internet helps me keep in touch with friends or family") belong to essentially different 
dimensions of online communication. While the first statement belongs to procreative dimension of online communication, the second is a typical transmissional one. Combining them within the same dimension will give a useless result due to the compensatory effect. A similar problem can be found in the works of Lien and Cao (2014) and Chang and Zhu (2011). In both papers, the authors identify the so-called sociality as one of the aspects of motivation for using SNS. In their view, the sociality is comprised of two motivations - connecting with old friends and meeting new people. Again, we argue that these are two completely different motivations and therefore cannot be combined in the same motivation dimension.

Furthermore, there are a few scales for measuring online interaction related activities, but only on Facebook. The most detailed is Joinson's (2008) scale which required the participants to rate the 46 uses and gratifications of Facebook activities. Ross (2009) also analyzed online sociability relying on a scale comprised of questions relating to the frequency of users' participation in different Facebook activities. One of the recent attempts has been the Gossip scale (Blazevic et al., 2014) although it mainly concerns online discussion activities. In marked contrast to these scales, our scale is not limited to a single dimension of online interaction, or a single online platform, but acknowledges a variety of communicational activities on diverse online platforms.

To confirm the multidimensionality of online procreativity based on previous research of online communication we have chosen several distinctive predictors, i.e. gender, SNS use and psychological features, and examined their association with different dimensions of online procreativity. It is important to add that we did not intent to explore deeper why each of these predictors was related to online procreativity but only to determine how they influenced different procreativity dimensions.

With regard to our theoretical framework and presented literature review, we hypothesized that:

H.1. Online procreativity is comprised of three different dimensions of online communication, i.e. public, based on anonymous and non-anonymous interaction and private, based on anonymous interaction.

H.2. Gender, SNS use and psychological features will be associated with general online procreativity as well as with three dimensions of online procreativity.

H.2a. Gender will be associated with the dimension of online procreativity based on private interaction with strangers (PvCBS), i.e. men will be positively and women negatively associated with PvCBS. 
H.2b. Intensity of SNS use will be positively associated with the dimension of online procreativity based on interaction with familiar people ( $\mathrm{PbCBF}$ ).

H.2c. Psychological features have substantially different influence depending on online procreativity dimension under observation. While we expect that loneliness and social anxiety will be positively associated with private interaction with strangers (PvCBS), on the other hand, we expect that social provision will be positively associated only with interaction between familiar people ( $\mathrm{PbCBF}$ ).

The justification for these hypotheses was based on an extensive body of research dealing with different aspects of online communication.

Previous research found that men are far more open to making new contacts online (Colley \& Maltby, 2008; Haferkamp et al., 2012; Muscanell \& Guadagno, 2012; Sheldon, 2008) while women tend to interact with familiar people (Fogel \& Nehmad 2009; Muscanell \& Guadagno, 2012). In line with that, we expect that gender will be very distinctive depending on different dimensions of procreativity under observation.

When it comes to SNS use, those who already have strong social skills may consider the internet as just another venue to get in touch with peers (Valkenburg \& Peter, 2007b; Kraut et al., 2002). SNS are found to be an important tool for maintaining relationships with already familiar people from everyday life (Ellison, Steinfield \& Lampe, 2011; Vitak, Ellison \& Steinfield, 2011). Accordingly, we can expect that those who use SNS more intensively, in terms of time spent on SNS, the number of SNS friends and share of strangers among SNS friends, will have the tendency to interact with familiar people.

Furthermore, from the perspective of the social capital theory, online communication can be instrumental in acquiring social provision (Jin, 2015; Pénard \& Poussing 2010; Vergeer \& Pelzer, 2009). Thus, those with higher social provision will rely on online communication to maintain personal network relationships, and hence are expected to be inclined towards online interaction with familiar people.

Previous studies have also shown that for lonely and/or socially anxious people, who are often struggling to make friends in their real lives, communicating online helps in establishing new relationships (McKenna, Green \& Gleason, 2002; Shalom et al., 2015; Valkenburg \& Peter, 2007b). Furthermore, those who are experiencing higher anxiety are expected to be reluctant to participate in a public group interaction, at least with familiar people, judging they would fear other people's negative comments, as they do in real life (Caplan, 2006; Lee \& Stapinski, 2012; Van den Heuvel et al., 2012; Yen et al., 2012). 


\section{Methodology and measurements}

\subsection{Participants}

A total of 546 students from the Belgrade University participated in the study. ${ }^{3}$ The questionnaires were administered by paper-pencil method during class time (haphazard sampling). The sample was comprised of 53.5\% women and $46.5 \%$ men, having an average 19.88 years (age range $18-31, \mathrm{SD}=1.92$ ).

\subsection{Measures}

Questionnaire - The questionnaire was comprised of 87 variables. The first section in the questionnaire, besides socio-demographic characteristics, measured respondent's general use of the Internet and SNS, the number of SNS friends and their structure in terms of old vs. new contacts. Other sections in the questionnaire were related to the following four scales.

Online procreativity - Participants rated how often they performed different online interaction activities indicated in 25 OPS items (expressed as statements) on a 7-point Likert scale from $1=$ never to $7=e v e r y d a y$. The development and validation of the OPS is described in the results section.

Social provisions - We used the social provision scale (Cutrona \& Russell, 1987) built based on Weiss (1974) work to assess the perception of social support in six domains: attachment, social integration, opportunity for nurturance, reassurance of worth, reliable alliance and guidance. Participants rated statements about their social support on a 4-point scale ranging from $1=$ strongly disagree to $4=$ strongly agree. The Cronbach's alpha for internal consistency was reported as 0.915 and in this study the Cronbach's alpha coefficient was 0.87 .

Loneliness - The 20-item UCLA Loneliness Scale (Russell et al., 1978) was used to assess participants' degree of global loneliness. Participants rated the items from $1=$ never to $4=$ always. The Cronbach's alpha for internal consistency was reported as 0.96 . In this study, the alpha for the scale was 0.94 and the mean in the current sample was $32.05(\mathrm{SD}=10.69)$, suggesting a relatively low level of loneliness on the average.

Social anxiety - The Brief Fear of Negative Evaluation scale (BFNE) was used to assess social anxiety about being negatively evaluated. The BFNE was selected for this purpose because it assesses the fears that are central to social anxiety disorder (Rapee \& Heimberg, 1997). The BFNE is a 12-item self-

3 The survey was conducted at five different faculties: Faculty of Philosophy, Faculty of Transport and Traffic Engineering, Faculty of Organizational Sciences, Faculty of Economics and Faculty of Political Sciences. 
report measure developed by Leary (1983) and adapted to Serbo-Croatian by Bezinovic (1988). The respondents indicated how each statement characterized them on a 5-point Likert-type scale (from $1=$ not at all characteristic of me to $5=$ extremely characteristic of me). The mean in the current sample was 32.15 $(\mathrm{SD}=8.56)$, suggesting a moderate level of social anxiety symptoms on average. The Cronbach's alpha for internal consistency was reported as 0.90 and in this study the Cronbach's alpha coefficient was 0.85 .

\section{The results}

Within the result section we will thoroughly elaborate on how the Online Procreativity Scale was developed and validated. After explaining how the initial item pool was selected, we proceed with the four-step procedure of developing and validating the OPS. First, we obtained PCA results for the entire set of 25 items and came up with a three-factor solution. In the second step, the OPS was narrowed to 10 items and subjected to PCA once more. Within the third step, we tested the OPS model by using CFA, maximum likelihood criterion. As the final step, we performed regression analysis in order to test construct validity.

\subsection{Developing Online Procreativity Scale - OPS}

In developing the OPS our aim was to create a tool for measuring communication related activities in cyberspace (i.e. social network sites (SNS), forums, chat rooms, blogs and online games). We started from our concept that online procreativity is a multidimensional phenomenon, each of whose dimensions should be measured by a comprehensive instrument. Our previous research on the matter (Petrović, 2009, 2012, 2013) allowed us to narrow the initial item pool to 25 items. Six items were taken from the first version of the OPS, used in a PhD thesis by Petrović (2012). Other items were selected based on a theoretical framework on general procreativity and its dimensions.

Moreover, in order to cover the full variety of online interactions we also used literature on making friends in cyberspace (Ellison, Steinfield \& Lampe, 2007; Muscanell \& Guadagno, 2012; Parks \& Floyd, 1996; Ploderer, Howard \& Thomas, 2008) for personal aspects of procreativity and research on virtual communities (Bender, Jimenez-Marroquin \& Jadad, 2011; Park, Kee \& Valenzuela, 2009; Zhang, Jiang \&Carroll, 2010) for public aspects of procreativity, as well as the items used in several different studies for general procreativity (Johnson \& Kulpa, 2007; Joinson, 2008; Ross, 2009).

For general procreativity, we created items that pointed to willingness to make new contacts and socialize in cyberspace (e.g. I meet new people online; 
I send friend requests to unknown people on social network sites; I hang out with people online). The items developed within the PvCBS dimension related to anonymous and private online communication (e.g. I chat with strangers online; When I am online I flirt with people that I have never met in person). For the $\mathrm{PbCBF}$ dimension we offered items pointing to public online communication between already familiar people (e.g. When online, I chat with people that I am personally acquainted with in "real" life; I make comments on my friends' statuses, photos and comments on social network sites). The $\mathrm{PbCBS}$ dimension was depicted by items related to anonymous public communication (e.g. I post on web forums, blogs, online games; I read other people's discussions on web forums, blogs, online games).

However, some items may seem as out of the strict definition of communication as a two-way process and it may be useful to give additional explanations regarding them. For example, the item: 'I read other people's discussions on web forums, blogs, online games' can be seen as such, but interaction in cyber space has many different aspects compared to the real world. The habit just to read and not to post online is an already described phenomenon of online interaction, known as lurking (Tobin, et al., 2015). Another example could be the item 'I view non friends photos on SNS' which was selected in order to address newer SNS platforms, like Instagram, where communication through photos is in the very essence of these platforms (Pittman \& Reich, 2016).

\subsection{Exploratory factor analysis of the OPS}

The 25 items of the OPS were subjected to principal component analysis (PCA) using SPSS V20 statistical software. Before we performed factor analysis, the suitability of data was assessed. The sample size of over 500 participants is well above the suggested minimum of 300 (Tabachnick \& Fidell, 2007). Furthermore, the correlation matrix revealed the presence of many coefficients of 0.3 or above. The Kaiser-Meyer-Olkin value was 0.857 , exceeding the recommended value of 0.6 (Kaiser, 1974) and the Bartlett's (1954) test of sphericity reached significance $\left(\chi^{2}=5499.478\right.$, $\mathrm{df}=300, \mathrm{p}<0.001)$, supporting the factorability of the correlation matrix. PCA revealed the presence of four components with eigenvalues exceeding 1, explaining respectively $25.57 \%$ (ev. 6.81), 12.14\% (ev.3.09), 9.06\% (ev. 2.39 ) and $4.98 \%$ (ev. 1.30) of the variance. Inspection of the scree plot using Cattell's (1966) scree test in combination with parallel analysis indicated a three-component solution. After that, we performed another PCA with three fixed factors and to aid the interpretation of these components, varimax rotation was performed. The solution explained $49.144 \%$ of the variance (Table 1). 
Table 1: Initial OPS (25 items) and the Respective Factor Loadings

\begin{tabular}{|c|c|c|c|}
\hline & \multicolumn{3}{|c|}{ Components/Factors } \\
\hline & PvCBS & $\mathrm{PbCBF}$ & $\mathrm{PbCBS}$ \\
\hline $\begin{array}{l}\text { When I am online I flirt with people that I have never met in } \\
\text { person }\end{array}$ & .81 & & \\
\hline $\begin{array}{l}\text { When I am online I socialize with people that I have never met } \\
\text { in person }\end{array}$ & .72 & & \\
\hline I enter into emotional relationships with people I met online & .70 & & \\
\hline I send friend requests to unknown people on SNS & 69 & & \\
\hline I chat with strangers online & .69 & & \\
\hline I socialize with people I met online in "real life" & .67 & & \\
\hline I meet new people online & .64 & & \\
\hline I meet people that I met online in person & .64 & & \\
\hline I accept friend requests from unknown people on SNS & .61 & & \\
\hline I enter into sexual relationships with people I met online & .56 & & \\
\hline I view my friends photos on SNS & & .81 & \\
\hline I check my friends' statuses and comments on SNS & & .77 & \\
\hline $\begin{array}{l}\text { I make comments on my friends' statuses, photos and comments } \\
\text { on SNS }\end{array}$ & & .74 & \\
\hline I post personal photos on SNS & & .68 & \\
\hline I hang out with people online & & .63 & \\
\hline I post my statuses on SNS & & .62 & \\
\hline $\begin{array}{l}\text { When online, I chat with people that I am personally acquainted } \\
\text { with in "real" life }\end{array}$ & & .59 & \\
\hline I view non friends' photos on SNS & & .54 & \\
\hline $\begin{array}{l}\text { While online, I flirt with people that I am personally acquainted } \\
\text { with in "real" life }\end{array}$ & & .45 & \\
\hline I participate in discussions on web forums, blogs, online games & & & .87 \\
\hline I post on web forums, blogs, online games & & & .85 \\
\hline $\begin{array}{l}\text { I comment on other people's posts on forums, blogs, online } \\
\text { games }\end{array}$ & & & .67 \\
\hline $\begin{array}{l}\text { I read other people`s discussions on web forums, blogs, online } \\
\text { games }\end{array}$ & & & .57 \\
\hline $\begin{array}{l}\text { I affiliate with groups, organizations, movements and } \\
\text { associations online. }\end{array}$ & & & .46 \\
\hline I visit online chat rooms & & & .39 \\
\hline
\end{tabular}

In the next step, using the criterion of 0.5 as the minimum value for acceptable factor loadings we excluded all items that did not meet this criterion (Cattell, 1978). After that, the inter-item correlation matrix was examined in order to identify redundancy among items, as well as to identify the items which correlated very low on the average (Clarke \& Watson, 1995). During this procedure, the items which had correlation coefficients above 0.7 and the items which correlated less than 0.15 on the average were excluded. This left us with 
10 items that were used for final EFA. In Table 2 we present descriptive statistics for 10 items and in Table 3 the correlations between them can be found.

Table 2: Descriptive statistics for 10 OPS items

\begin{tabular}{|c|c|c|c|c|c|c|c|}
\hline Mark & Items & $\mathrm{N}$ & Mean & Median & Std. Dev. & Skewness & Kurtosis \\
\hline Accept & $\begin{array}{l}\text { I accept friend requests } \\
\text { from unknown people } \\
\text { on SNS }\end{array}$ & 543 & 2.42 & 2.00 & 1.52 & 1.21 & 1.25 \\
\hline Send & $\begin{array}{l}\text { I send friend requests to } \\
\text { unknown people on SNS }\end{array}$ & 542 & 1.88 & 1.00 & 1.28 & 1.69 & 2.92 \\
\hline Chat & $\begin{array}{l}\text { I chat with strangers } \\
\text { online }\end{array}$ & 542 & 1.86 & 1.00 & 1.27 & 1.77 & 3.29 \\
\hline Social & $\begin{array}{l}\text { When I am online I } \\
\text { socialize with people } \\
\text { that I have never met in } \\
\text { person }\end{array}$ & 543 & 1.94 & 1.00 & 1.37 & 1.76 & 2.99 \\
\hline Post & $\begin{array}{l}\text { I post on web forums, } \\
\text { blogs, online games }\end{array}$ & 538 & 2.26 & 1.00 & 1.65 & 1.27 & .75 \\
\hline Discuss & $\begin{array}{l}\text { I participate in discussions } \\
\text { on web forums, blogs, } \\
\text { online games }\end{array}$ & 540 & 2.25 & 2.00 & 1.63 & 1.30 & .86 \\
\hline Read & $\begin{array}{l}\text { I read other people's } \\
\text { discussions on web } \\
\text { forums, blogs, online } \\
\text { games }\end{array}$ & 545 & 3.30 & 3.00 & 1.91 & .36 & -1.03 \\
\hline Photos & $\begin{array}{l}\text { I post personal photos } \\
\text { on SNS }\end{array}$ & 535 & 3.47 & 3.00 & 1.58 & .35 & -.07 \\
\hline Hang & $\begin{array}{l}\text { I hang out with people } \\
\text { online }\end{array}$ & 540 & 4.28 & 4.00 & 2.01 & -.17 & -1.18 \\
\hline Comment & $\begin{array}{l}\text { I make comments on my } \\
\text { friends' statuses, photos } \\
\text { and comments on SNS }\end{array}$ & 545 & 3.96 & 4.00 & 1.87 & -.09 & -.99 \\
\hline
\end{tabular}

Table 3: Inter-item correlation matrix for 10 OPS items

\begin{tabular}{|c|c|c|c|c|c|c|c|c|c|c|}
\hline & Accept & Send & Chat & Social & Post & Discuss & Read & Photos & Hang & Comment \\
\hline Accept & 1.00 & $.56^{\star *}$ & $.46^{\star *}$ & $.46^{\star \star}$ & .02 & .01 & .05 & $.20^{* *}$ & $.19^{* *}$ & $.22^{\star *}$ \\
\hline Send & & 1.00 & $.50^{\star *}$ & $.49^{* *}$ & $.10^{*}$ & .07 & .01 & $.12^{*}$ & $.19^{* *}$ & $.21^{\star *}$ \\
\hline Chat & & & 1.00 & $.66^{* *}$ & $.16^{\star *}$ & $.14^{* *}$ & $.08^{*}$ & $.10^{*}$ & $.19^{* *}$ & $.19^{* *}$ \\
\hline Social & & & & 1.000 & $.25^{\star *}$ & $.20^{\star *}$ & $.13^{* *}$ & $.13^{\star *}$ & $.27^{\star *}$ & $.25^{\star *}$ \\
\hline Post & & & & & 1.00 & $.74^{\star *}$ & $.34^{\star *}$ & $.15^{\star *}$ & $.21^{\star *}$ & $.16^{* *}$ \\
\hline Discuss & & & & & & 1.00 & $.41^{\star *}$ & $.11^{\star *}$ & $.17^{\star *}$ & $.13^{* *}$ \\
\hline Read & & & & & & & 1.00 & $.10^{*}$ & $.22^{* *}$ & $.17^{\star *}$ \\
\hline Photos & & & & & & & & 1.00 & $.43^{* *}$ & $.49^{* *}$ \\
\hline Hang & & & & & & & & & 1.00 & v. $50^{\star *}$ \\
\hline Comment & & & & & & & & & & 1.00 \\
\hline
\end{tabular}


The 10 items of the OPS were subjected to EFA with maximum likelihood solution and Promax rotation (Kappa $=4)$. The Kaiser-Meyer-Olkin value was 0.740, exceeding the recommended value of 0.6 (Kaiser, 1974) and the Bartlett's (1954) test of sphericity reached significance $\left(\chi^{2}(45)=1634.859\right.$, $\mathrm{p}<0.001)$, supporting the factorability of the correlation matrix. EFA revealed the presence of three components with eigenvalues exceeding 1, explaining respectively $24.26 \%$ (ev.243), $18.33 \%$ (ev.1.83) and $10.44 \%$ (ev. 1.04) of the variance. Inspection of the scree plot using Cattell's (1966) scree test in combination with parallel analysis indicated a three-component solution. Altogether, with three identified components we explained cumulatively $53.03 \%$ of variance. The results of EFA are presented in Table 4, while factor correlation matrix can be found in Table 5 .

Table 4: Items Retained in the OPS (10 items) and the Respective Factor Loadings

\begin{tabular}{|c|c|c|c|}
\hline & \multicolumn{3}{|c|}{ Components/Factors } \\
\hline & PvCBS & PbCBS & $\mathrm{PbCBF}$ \\
\hline I chat with strangers online & .81 & & \\
\hline $\begin{array}{l}\text { When I am online I socialize with people that I have never met } \\
\text { in person }\end{array}$ & .77 & & \\
\hline I send friend requests to unknown people on social network sites & .67 & & \\
\hline I accept friend requests from unknown people on social network sites & .63 & & \\
\hline I participate in discussions on web forums, blogs, online games & & .93 & \\
\hline I post on web forums, blogs, online games & & .81 & \\
\hline I read other people's discussions on web forums, blogs, online games & & .42 & \\
\hline $\begin{array}{l}\text { I make comments on my friends' statuses, photos and comments } \\
\text { on SNS }\end{array}$ & & & .74 \\
\hline I post personal photos on social network sites & & & 67 \\
\hline I hang out with people online & & & .63 \\
\hline
\end{tabular}

Table 5: Factor Correlation Matrix

\begin{tabular}{lccc}
\hline Factor & 1 & 2 & 3 \\
\hline 1 & 1.00 & .21 & .36 \\
2 & & 1.00 & .24 \\
3 & & & 1.00 \\
\hline
\end{tabular}

\subsection{Confirmatory Factor Analysis of the OPS}

Next step was to perform Confirmatory Factor Analysis (CFA), maximum likelihood criterion, in order to validate three subscales of the OPS, as well as latent structure of the OPS. The results of the CFA are presented in Figure 3. We estimated goodness-of-fit based on standard indexes that are used in CFA (Bentler, 1990; Schermelleh-Engel, Moosbrugger \& Müller, 2003). It is proposed that relative chi-square is supposed to be less than $2(\mathrm{Cmin} / \mathrm{df}<2)$. 
It is recommended for the good model fit that the Goodness of Fit Index (GFI), Adjusted Goodness of Fit Index (AGFI), as well as Comparative Fit Index (CFI) are supposed to be higher than 0.90, while Normed Fit Index (NFI) is supposed to be higher than 0.95. Additionally, Root Mean Square Error of Approximation (RMSEA) indicates excellent fit if the value is lower than 0.05 . In our model, we identify that Chi-square (df, 22) $=33.287, \mathrm{Cmin} /$ $\mathrm{df}=1.513, \mathrm{AGFI}=.966, \mathrm{CFI}=.993, \mathrm{TLI}=.985, \mathrm{SRMR}=.030$ and $\mathrm{RMSEA}=.033$. Moreover, for the chosen model we report AIC $=99.287$ and $\mathrm{BIC}=236.257$. Alternatively, we tested two more models - the hierarchical one and the independent three factor model. ${ }^{4}$ We checked linearity and identified that $\mathrm{R}^{2}=.291, \mathrm{~F}(1,464)=190.654, \mathrm{p}<0.001$. Linear relationship was proved to be superior compared to other possible relationship. Moreover, we checked multicolinearity and identified VIF=2.462 and Conditional Index $=11.053$. Therefore, according to the obtained CFA results, the OPS proved to be an existent latent structure of online procreativity, consisting of three dimensions.

Thus, the entire set of presumed goodness of fit criteria is met in CFA of the OPS that was performed. The only item in the overall structure that could be questioned is 'read' since standardized regression weight was relatively low (.42), as well as the value of the squared multiple correlation coefficient (.19).

As it can be observed, after controlling for covarying effects, we still detected a strong correlation between PVCBS and PBCBF ( $r=.36)$, while the other two correlation coefficients between factors of the OPS were rather low.

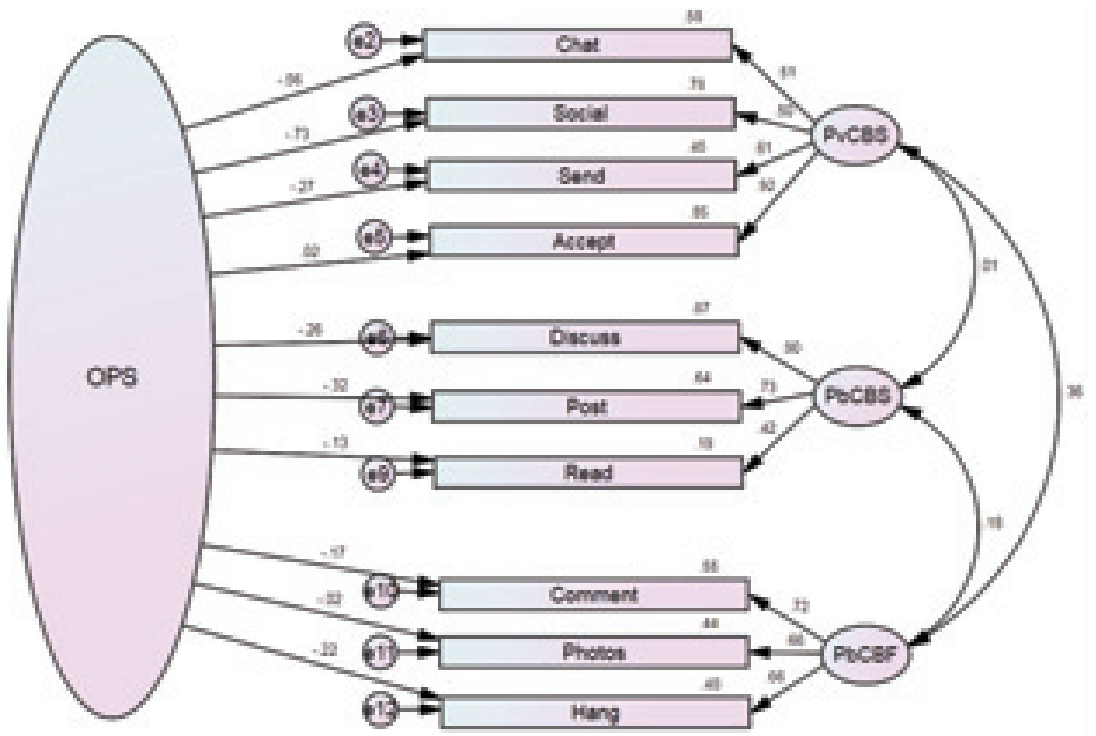

Figure 3: Confirmatory Factor Analysis - OPS latent structure

4 For hierarchical model, $\mathrm{AIC}=824.826$ and $\mathrm{BIC}=907.838$; for independent model, $\mathrm{AIC}=164.908$ and $\mathrm{BIC}=260.371$. 
The factor analysis (EFA and CFA) confirmed our first hypothesis regarding the presence of three dimensions of online procreativity. Consequently, we developed three sub-scales of three dimensions of procreativity. Those were $\operatorname{PvCBS}(\alpha=.807), \operatorname{PbCBS}(\alpha=.731)$ and PbCBF $(\alpha=.735)$. All three scales were numerically constructed as factor regression scores. Finally, we constructed the OPS as a total score of three dimensions of procreativity (also as a factor score). Descriptives and distribution of the overall score of procreativity (OPS) are shown in Table 6 and Figure 4.

Table 6: Descriptive statistics of the OPS

\begin{tabular}{lcc}
\hline $\mathrm{N}$ & & 502 \\
Mean & & .00 \\
Median & .13 \\
Std. Deviation & 1.00 \\
Skewness & .76 \\
Kurtosis & & .76 \\
Minimum & & -1.81 \\
Maximum & & 3.67 \\
& 25 & -.67 \\
Percentiles & 50 & -.13 \\
& 75 & .51 \\
& 90 & 1.40 \\
\hline
\end{tabular}

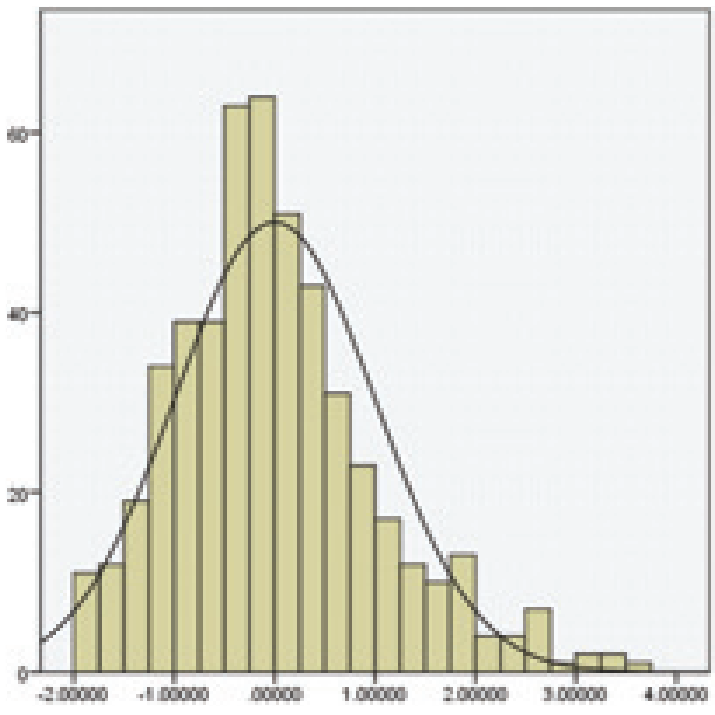

\subsection{The OLS regression analysis}

In order to enrich the validity of the OPS and test our second hypothesis, in the third step a regression analysis was performed, using PvCBS, PbCBS, $\mathrm{PbCBF}$ and OPS as dependent variables. We conducted the regression procedure in two steps. The first step of the regression analysis was designed to examine the predictability of demographic and SNS use variables as independent variables. The second step of the OLS examined the predictability of psychological variables, i.e. anxiety, loneliness and different aspects of social provision of the OPS.

In Table 7 we have presented descriptive statistics for the entire set of independent variables used in regression models, and in Table 8 the results of the OLS are presented. 
Table 7: Descriptive statistics of predictors of the OPS

\begin{tabular}{lccccc}
\hline PREDICTORS & $\mathrm{N}$ & Mean & Std. Dev. & Minimum & Maximum \\
\hline Big city (+ 1 mil resid.) & 546 & .52 & .50 & .00 & 1.00 \\
City (+ 100000 resid.) & 546 & .08 & .27 & .00 & 1.00 \\
Time spent on SNS & 546 & 7.19 & 1.69 & 1.00 & 8.00 \\
Number of friends on SNS & 504 & 591.22 & 528.38 & .00 & 5000.00 \\
Unknown SNS friends & 514 & 3.43 & 1.08 & 1.00 & 5.00 \\
Attachment & 540 & .00 & 1.00 & -3.97 & 1.00 \\
Social integration & 533 & .00 & 1.00 & -5.15 & 1.05 \\
Reassurance of Worth & 524 & .00 & 1.00 & -2.97 & 1.65 \\
Reliable Alliance & 541 & .00 & 1.00 & -5.86 & .62 \\
Guidance & 541 & .00 & 1.00 & -6.44 & .58 \\
Opportunity for Nurturance & 532 & .00 & 1.00 & -4.81 & 1.15 \\
Anxiety & 535 & .00 & .94 & -1.39 & 2.76 \\
Loneliness & 539 & .00 & .96 & -1.21 & 4.42 \\
Trust & 458 & 4.64 & 2.39 & 0 & 10 \\
\hline
\end{tabular}

When it comes to the results of regression models, first it should be noted that demographic and SNS use variables have explained a considerably higher proportion of variance of the dependent variables compared to the psychological variables. Comparatively, the whole set of independent variables was the most fruitful predictor of PvCBS, since it explained almost $32 \%$ of the dependent variable. Explained variance for $\mathrm{PbCBF}$ was also rather high; more accurately, independent variables explained more than $20 \%$ of this dimension. As far as the overall OPS score is concerned, we have established that the entire set of predictors explained $22.6 \%$ variance, respectively. On the other hand, the predictors in the model were not very helpful in explaining $\mathrm{PbCBS}$, since they explained only $3.8 \%$ of variance of this dependent variable.

The results of the regression analysis showed that, as we hypothesized, demographic, SNS use and psychological variables had a substantially different influence, depending on online communication dimension under observation. Demographic variables were proved to be a significant predictor of general procreativity. However, only if we take into account different procreativity dimensions we can observe that demographic variables

5 Anxiety, Loneliness and the entire aspects of Social Provision are numerically presented as regression factor scores. The variables numerically represent $\mathrm{z}$-standardized scores, i.e. with the mean value of 0.00, and STD 0.1. To put it simply, each observation on these variables numerically represents how many STD it is distanced from the mean. Gender, Big city and City are dummy variables. The number of friends is an authentic interval scale, while unknown friends is a five levels ordinal scale (from 1 - do not know more than $75 \%$ to 5 - knows everyone). Social trust is measured with a single 10-point scale item (most people can be trusted). 
primarily influenced PvCBS dimensions, while other two were not associated with these predictors.

Table 8: OLS - predictors of the OPS

\begin{tabular}{|c|c|c|c|c|c|c|c|c|}
\hline \multirow{3}{*}{$\frac{\text { PREDICTORS }}{\text { Intercept }}$} & \multicolumn{2}{|c|}{ PvCBS } & \multicolumn{2}{|c|}{$\mathrm{PbCBS}$} & \multicolumn{2}{|c|}{$\mathrm{PbCBF}$} & \multicolumn{2}{|c|}{ OPS } \\
\hline & -.21 & -.24 & $-1.37^{* * *}$ & $-1.37^{* * *}$ & $-2.36^{* * *}$ & $-2.14^{\star * *}$ & $-1.99^{* * *}$ & $-1.89^{\star * *}$ \\
\hline & $(-.51)$ & $(-.59)$ & $(-2.84)$ & $(-2.77)$ & $(-6.21)$ & $(-5.56)$ & $(-4.38)$ & $(-4.09)$ \\
\hline \multirow{2}{*}{ Gender/Male } & $.55^{\star \star \star}$ & $.56^{\star * *}$ & .18 & .19 & -.03 & .01 & $.34^{* * *}$ & $.37^{\star * *}$ \\
\hline & $(6.34)$ & $(6.27)$ & (1.73) & (1.71) & $(-0.32)$ & $(0.07)$ & (3.51) & (3.65) \\
\hline \multirow{2}{*}{ Big city } & $.21^{\star \star}$ & $.19^{* *}$ & .15 & .17 & .08 & .09 & $.22^{\star *}$ & $.22^{\star *}$ \\
\hline & $(2.32)$ & $(2.10)$ & $(1.41)$ & $(1.60)$ & $(0.95)$ & $(1.05)$ & $(2.13)$ & $(2.16)$ \\
\hline \multirow{2}{*}{ City } & .10 & .10 & .36 & .31 & .20 & .22 & .31 & .31 \\
\hline & $(.61)$ & $(.67)$ & $(1.87)$ & $(1.63)$ & $(1.34)$ & $(1.50)$ & $(1.72)$ & $(1.72)$ \\
\hline \multirow{2}{*}{ Time spent on SNS } & .05 & .04 & $.14^{* *}$ & $.13^{* *}$ & $.28^{* * *}$ & $.26^{* * *}$ & $.24^{* * *}$ & $.22^{* * *}$ \\
\hline & $(1.00)$ & $(.81)$ & $(2.31)$ & $(2.22)$ & $(5.94)$ & $(5.52)$ & $(4.24)$ & $(3.93)$ \\
\hline \multirow{2}{*}{$\begin{array}{l}\text { Number of friends } \\
\text { on SNS }\end{array}$} & $.00^{* * *}$ & $.00^{* * *}$ & .00 & .00 & $.00^{* * *}$ & $.00^{* * *}$ & $.00^{* * *}$ & $.00^{* * *}$ \\
\hline & $(4.62)$ & $(4.78)$ & $(1.14)$ & $(1.22)$ & $(4.68)$ & $(4.38)$ & $(4.80)$ & $(4.77)$ \\
\hline \multirow{2}{*}{$\begin{array}{l}\text { Unfamiliar SNS } \\
\text { friends }\end{array}$} & $-.22^{\star * *}$ & $-.22^{* * *}$ & .03 & .04 & .03 & .00 & -.09 & -.1 .0 \\
\hline & $(-4.86)$ & $(-4.71)$ & $(0.50)$ & $(0.68)$ & $(0.66)$ & $(0.01)$ & $(-1.70)$ & $(-1.85)$ \\
\hline \multirow{2}{*}{ Loneliness } & & $.18^{* * *}$ & & .03 & & .11 & & $.17^{\star *}$ \\
\hline & & $(2.84)$ & & $(0.44)$ & & $(1.80)$ & & $(2.33)$ \\
\hline \multirow{2}{*}{ Reliable Alliance } & & $.15^{\star *}$ & & .08 & & $.13^{* *}$ & & $.19^{* * *}$ \\
\hline & & $(2.56)$ & & $(1.08)$ & & $(2.32)$ & & $(2.73)$ \\
\hline \multirow{2}{*}{$\begin{array}{l}\text { Opportunity for } \\
\text { Nurturance }\end{array}$} & & .07 & & .08 & & .05 & & .10 \\
\hline & & $(1.41)$ & & $(1.29)$ & & $(1.04)$ & & $(1.70)$ \\
\hline \multirow{2}{*}{ Social integration } & & .00 & & -.12 & & .06 & & -.01 \\
\hline & & $(.02)$ & & $(-1.79)$ & & $(1.16)$ & & $(-0.24)$ \\
\hline \multirow{2}{*}{ Attachment } & & -.1 .0 & & .04 & & -.04 & & -.06 \\
\hline & & $(-1.41)$ & & $(0.47)$ & & $(-0.68)$ & & $(-0.75)$ \\
\hline \multirow{2}{*}{ Reassurance of Worth } & & -.02 & & .04 & & .04 & & .03 \\
\hline & & $(-.38)$ & & $(0.57)$ & & $(0.74)$ & & $(0.42)$ \\
\hline \multirow{2}{*}{ Guidance } & & -.03 & & -.13 & & .02 & & -.06 \\
\hline & & $(-.53)$ & & $(-1.68)$ & & $(0.34)$ & & $(-0.83)$ \\
\hline \multirow{2}{*}{ Anxiety } & & -.02 & & .07 & & .06 & & .05 \\
\hline & & $(-.48)$ & & $(1.32)$ & & $(1.30)$ & & $(0.97)$ \\
\hline \multirow{2}{*}{ Trust } & & .02 & & -.01 & & .00 & & .01 \\
\hline & & $(.93)$ & & $(-0.25)$ & & $(0.24)$ & & $(0.43)$ \\
\hline Adjusted $\mathrm{R}^{2}$ & .29 & .32 & .03 & .04 & .18 & .20 & .20 & .23 \\
\hline Model 1 F $(6,338)$ & $24.27^{* * *}$ & $11.71^{* * *}$ & $2.56^{* *}$ & $1.90^{* *}$ & $13.34^{* * *}$ & $6.90^{* * *}$ & $15.21^{\star * *}$ & $7.68^{\star * *}$ \\
\hline Model 2 F $(15,329)$ & & & & & & & & \\
\hline $\begin{array}{l}\text { Sum of Squares of the } \\
\text { model }\end{array}$ & 90.55 & 104.69 & 13.50 & 24.83 & 43.92 & 54.86 & 71.75 & 87.55 \\
\hline $\begin{array}{l}\text { Sum of Squares of } \\
\text { residual }\end{array}$ & 210.18 & 196.04 & 297.66 & 286.33 & 185.43 & 174.49 & 265.73 & 249.93 \\
\hline
\end{tabular}

${ }^{* * *} \mathrm{p}<.01,{ }^{* *} \mathrm{p}<.05$ (T test is reported in parentheses)

SNS use also had great influence on general procreativity, as well as on its different dimensions. For example, not only that the number of SNS 
friends was a predictor of general procreativity, it has also been shown that the structure of SNS friends, in terms of share of strangers among SNS friends, was an important predictor. While PvCBS was predicted by both variables related to SNS friends, general procreativity as well as PbCBF was predicted only by the number of SNS friends. This finding is in line with our dimension approach because one can expect that those with the tendency to communicate anonymously ( $\mathrm{PvCBS}$ ) will have a higher share of strangers among their SNS friends.

Main psychological variables were not significant predictors of procreativity. This is something that should be further investigated in future research. However, one of the most discussed psychological aspects in terms of online interaction, loneliness, has shown to be an important predictor of just one specific dimension - PvCBS, as well as procreativity in general. This finding will be elaborated upon in further discussion.

\section{Discussion}

The aim of the present study was to explore the dimensions of online procreativity. We understand procreative online communication as a person's tendency to use the internet as a virtual third place (Oldenburg \& Brissett, 1982; Soukup, 2006) where new social contacts or communities are established. Our standpoint is that procreative online communication differs substantially from using the internet transmissionally as a peer-topeer communication channel between people who are familiar with one another. In other words, being procreative means that social actors are using a communication technology in a completely new manner, i.e. they produce new social space built upon interactions in virtual surroundings both with strangers and familiar people from everyday life.

\subsection{Dimensions of procreativity}

In order to measure the level of online procreativity and its different dimensions we developed the Online Procreativity Scale - OPS. One feature of the OPS is that the same overall procreativity score does not necessarily point to the same procreativity dimension. Of course, this is a common feature of all multi-dimensional scales but we highlighted this because, as we explained in the introduction, there was a widespread tendency to analyze online communication as a one-dimensional phenomenon. Now, by using the OPS, we can determine not just that a person has a tendency to use the internet in a procreative fashion but also the dimension of procreativity that $s /$ he fits in.

We assumed (H.1) and through empirical research confirmed that online procreativity consists of three dimensions (see Figures 1,2): the $\mathrm{PbCBF}$ dimension, which refers to public interaction with familiar people 
in cyberspace, the $P v C B S$ dimension, which pertains to private, one-on-one interaction with anonymous or unfamiliar people in cyberspace, and the $\mathrm{PbCBS}$ dimension that refers to public interaction with anonymous people in cyberspace, predominantly in forums, blogs and online games.

One of the key findings of our study was that online procreativity is associated with gender, city size, the time spent on SNS, the number of friends on SNS and the share of strangers within friends on SNS, along with psychological variables - reliable alliance and loneliness. In other words, the more procreative individuals are those who are men, who live in big cities, who spend more time on SNS, who have more SNS friends and more strangers among SNS friends, as well as those who are lonely and in need of a reliable alliance.

The second finding of our study served to justify the need to distinguish between different aspects of online procreativity. The OLS regression showed that predictors have diverse influence depending on the procreativity dimension under observation. None of the seven identified predictors was common to all three dominant dimensions, while only three predictors were associated with both the PvCBS and the PbCBF dimension.

Let us now illustrate how gender, SNS use and psychological features are associated with general online procreativity as well as with different dimensions of online procreativity.

\subsection{Gender and procreativity}

If we consider gender and its predictability of general procreativity (OPS) we may conclude that males are much more procreative compared to women. However, when looking at sub-scales results a more accurate picture emerges. Gender is actually a predictor of the tendency to communicate with strangers in private, which is in line with our H.2a, but when it comes to predicting public interaction in cyberspace, it has no influence whatsoever. This corresponds with the findings from the previous studies that men are far more open to making new contacts online (Haferkamp et al., 2012; Muscanell \& Guadagno, 2012; Sheldon, 2008; Colley \& Maltby, 2008). Nevertheless, the conclusion arising from our results was that women are no less prone to interact in cyberspace provided that the interaction involves individuals they already know and trust, as it was reported in several other studies (Muscanell \& Guadagno, 2012; Fogel \& Nehmad 2009).

\subsection{SNS and procreativity}

The obtained results imply that the time spent on SNS clearly predicts general procreativity. However, private communication with strangers is not associated with this SNS use predictor, while the relationship is evident for 
both dimensions based on public group communication, which is in line with our H.2b. This finding, along with some other results concerning SNS, affords us an opportunity to understand better the social function of SNS platforms. We can argue that SNS platforms support the ritual (Carey, 2002) or constitutive (Craig, 2007) function of online communication. For those who have a tendency to publicly interact in cyberspace, communication is a constitutive element of online community i.e. it is a goal in itself. Thus, public interaction on SNS involves more people and, unlike one-to-one interaction, it is time-consuming.

On the other hand, those who prefer to communicate with unfamiliar people in private are more instrumental, meaning that they use SNS platforms as a means to reach a desired person as they have predefined motives. These findings can also be understood in the light of the social capital theories (Vitak, Ellison \& Steinfield, 2011; Ellison, Steinfield \& Lampe, 2011; Pénard \& Poussing 2010; Vergeer \& Pelzer, 2009).

\subsection{Loneliness and procreativity}

Among psychological features, only loneliness was found to be a clear predictor of online procreativity while influence of two other features (social anxiety and social provision) was ambiguous. Consequently, our H.2c was only partially confirmed. We did not find that social anxiety was associated with online procreativity at all, although findings of some previous studies gave us the reason to hypothesize this (Lee \& Stapinski, 2012; Yen et al., 2012; Caplan, 2006; Van den Heuvel et al., 2012). Social anxiety might be related to some other aspect of online communication other than online procreativity. However, this is to be further researched.

When it comes to social provision, only reliable alliance was shown to be a distinctive predictor of online procreativity while other dimensions of social provision remained without any influence. However, reliable alliance was associated only with public interaction between friends as we hypothesized.

Perhaps the most interesting result was the one relating to the strong relationship between loneliness and procreativity in general. This was a very important finding in light of the previous research on the relationship between online communication and loneliness. Although extensively discussed in literature, scholars remain equivocal on this matter. If we follow the logic of some of the previous studies we could simply conclude that being lonely enhances the willingness to communicate online (Sheldon, 2008; Lou et al., 2012). However, having been able to exploit different communication dimensions allowed us to understand better how loneliness affects online interaction. Our results revealed that being lonely strongly predicted merely 
the tendency towards private anonymous communication, while public online communication was unaffected by loneliness. This further underpins our standpoint regarding the need to address the multidimensionality of online communication since it is very difficult to find definite relationships between a given psychological predisposition and online communication in general. Neglecting the multidimensionality of online communication contributes to a growing number of studies with apparently contradictory results. The most obvious examples are the compensation and the-rich-get-richer theories (Kraut et al., 2002; Van Zalk et al., 2011; McKenna, Green \& Gleason, 2002; Valkenburg \& Peter, 2007b), which offer completely opposite views on the function of online communication. We suggest that these two perspectives are not necessarily mutually exclusive. According to our results we can conclude, in accordance with compensation theories, that communicating online helps lonely people, struggling to make friends in real life, to establish relationships. However, we also found that public communication online is not associated with loneliness, which can lead us to a conclusion consistent with the-richget-richer theories - those who already have strong social skills may consider cyberspace as just another social place to get in touch with other, familiar or unfamiliar, people.

\subsection{Limitations and future research}

Of course, this paper is not without limitations. First of all, the respondents were students so the analysis of the influence of age or level of education on online procreativity was limited to some extent. This practical constraint ought to be overcome given that existing studies (Valkenburg \& Peter, 2007a, 2007b) have shown that the interaction in cyber space varies significantly according to age. This is particularly the case with meeting new people because young people tend to be more reserved than their older counterparts. Thus, a larger and more heterogeneous sample is recommended for future research.

Furthermore, the predictors we used were the least contributive in explaining the dimension referring to public anonymous online interaction. This should be elaborated on both from the perspective of the predictors and the dimension itself. It is possible that our predictors were not explanatory enough. For example, if loneliness had been analyzed in more detail using an instrument that comprises both emotional and social loneliness (Weiss, 1974) the public anonymous communication might have been associated with a certain aspect of loneliness. However, it is possible that this dimension reflects a specific procreativity behaviour and should therefore be further researched. 


\section{References}

Bargh, J. A., \& McKenna, K. Y. (2004). The Internet and social life. Annu. Rev. Psychol., 55, 573-590.

Bartlett, M.S. (1954). A note on the multiplying factors for various chi square approximations. Journal of the Royal Statistical Society, Series B, 16, 296-298

Bender, J. L., Jimenez-Marroquin, M. C., \& Jadad, A. R. (2011). Seeking support on Facebook: a content analysis of breast cancer groups. Journal of medical Internet research, 13(1).

Bentler, P. M. (1990). Comparative fit indexes in structural models. Psychological bulletin, 107(2), 238.

Bezinović, P. (1988). Prikaz skala za mjerenje nekih aspekata samopoimanja. U: N. Anić (Ed.) Praktikum iz kognitivne i bihevioralne terapije, Zagreb: DPH. (In Croatian)

Blazevic, V., Wiertz, C., Cotte, J., De Ruyter, K., \& Keeling, D. I. (2014). GOSIP in cyberspace: Conceptualization and scale development for general online social interaction propensity. Journal of Interactive Marketing, 28(2), 87-100.

Boase, J. (2008). Personal networks and the personal communication system: Using multiple media to connect. Information, Communication \& Society, 11(4), 490-508.

Caplan, S. E. (2006). Relations among loneliness, social anxiety, and problematic Internet use. CyberPsychology \& Behavior, 10(2), 234-242.

Carey, J. (2002). A cultural approach to communication. McQuail's reader in mass communication theory, 36-45.

Cattell, R. B. (1966). The scree test for the number of factors. Multivariate behavioral research, 1(2), 245-276.

Cattell, R. B. (1978). The scientific use of factor analysis. New York: Plenum Press.

Chan, M. (2011). Shyness, sociability, and the role of media synchronicity in the use of computer-mediated communication for interpersonal communication. Asian Journal of Social Psychology, 14(1), 84-90.

Chang, Y. P., \& Zhu, D. H. (2011). Understanding social networking sites adoption in China: A comparison of pre-adoption and post-adoption. Computers in Human behavior, 27(5), 1840-1848.

Cheek, J. M., \& Buss, A. H. (1981). Shyness and sociability. Journal of personality and social psychology, 41(2), 330.

Correa, T., Hinsley, A. W., \& De Zuniga, H. G. (2010). Who interacts on the Web?: The intersection of users' personality and social media use. Computers in Human Behavior, 26(2), 247-253.

Craig, R. T. (1999). Communication theory as a field. Communication theory, 9(2), 119-161.

Craig, R. T. (2007). Pragmatism in the field of communication theory. Communication Theory, 17(2), 125-145.

Cutrona, C. E., \& Russell, D. W. (1987). The provisions of social relationships and adaptation to stress. In W.H. Jones and D. Perlman (eds.) Advances in personal relationships, 1(1), Greenwich, CT: JAI Press. 37-67. 
Colley, A., \& Maltby, J. (2008). Impact of the Internet on our lives: Male and female personal perspectives. Computers in human behavior, 24(5), 2005-2013.

Desjarlais, M., \& Willoughby, T. (2010). A longitudinal study of the relation between adolescent boys and girls' computer use with friends and friendship quality: Support for the social compensation or the rich-get-richer hypothesis?. Computers in Human Behavior, 26(5), 896-905.

Dimmick, J., Feaster, J. C., \& Ramirez, A. (2011). The niches of interpersonal media: Relationships in time and space. New Media \& Society, 13(8), 1265-1282.

Ellison, N. B., Steinfield, C., \& Lampe, C. (2011). Connection strategies: Social capital implications of Facebook-enabled communication practices. New media \& society, 13, 873-892.

Ellison, N. B., Steinfield, C., \& Lampe, C. (2007). The benefits of Facebook "friends:" Social capital and college students' use of online social network sites. Journal of Computer-Mediated Communication, 12(4), 1143-1168

Fogel, J., \& Nehmad, E. (2009). Internet social network communities: Risk taking, trust, and privacy concerns. Computers in human behavior, 25(1), 153-160.

Grinter, R. E., \& Palen, L. (2002). Instant messaging in teen life. In Proceedings of the 2002 ACM conference on Computer supported cooperative work (pp. 21-30). ACM.

Haferkamp, N., Eimler, S. C., Papadakis, A. M., \& Kruck, J. V. (2012). Men are from Mars, women are from Venus? Examining gender differences in self-presentation on social networking sites. Cyberpsychology, Behavior, and Social Networking, 15(2), 91-98.

Hogan, B., Dutton, W. H., \& Li, N. (2011). A global shift in the social relationships of networked individuals: Meeting and dating online comes of age. In William H., A Global Shift in the Social Relationships of Networked Individuals: Meeting and Dating Online Comes of Age

Hwang, Y. (2011). Is communication competence still good for interpersonal media?: Mobile phone and instant messenger. Computers in Human Behavior, 27(2), 924-934.

Jin, C. H. (2015). The role of Facebook users' self-systems in generating social relationships and social capital effects. New Media \& Society, 17(4), 501-519.

Johnson, G. M., \& Kulpa, A. (2007). Dimensions of online behavior: Toward a user typology. CyberPsychology \& Behavior, 10(6), 773-780.

Joinson, A. N. (2008). Looking at, looking up or keeping up with people?: motives and use of facebook. In Proceedings of the SIGCHI conference on Human Factors in Computing Systems (pp. 1027-1036). ACM.

Kaiser, H. F. (1974). An index of factorial simplicity. Psychometrika, 39(1), 31-36.

Kang, S. (2007). Disembodiment in online social interaction: Impact of online chat on social support and psychosocial well-being. CyberPsychology \& Behavior, 10(3), 475-477.

Kim, H., Kim, G. J., Park, H. W., \& Rice, R. E. (2007). Configurations of relationships in different media: FtF, email, instant messenger, mobile phone, and SMS. Journal of Computer-Mediated Communication, 12(4), 1183-1207.

Kraut R, Kiesler S, Boneva B, Cummings J, Helgeson V, Crawford, A. (2002). Internet paradox revisited. Journal of Social Issues, 58, 49-74. 
Leary, M. R. (1983). A brief version of the Fear of Negative Evaluation Scale. Personality and Social Psychology Bulletin, 9(3), 371-375.

Lee, B. W., \& Stapinski, L. A. (2012). Seeking safety on the internet: relationship between social anxiety and problematic internet use. Journal of anxiety disorders, 26(1), 197-205.

Leung, L. (2001). College student motives for chatting on ICQ. New Media \& Society, 3(4), 483-500.

Licoppe, C., \& Smoreda, Z. (2005). Are social networks technologically embedded?: How networks are changing today with changes in communication technology. Social networks, 27(4), 317-335.

Lien, C. H., \& Cao, Y. (2014). Examining WeChat users' motivations, trust, attitudes, and positive word-of-mouth: Evidence from China. Computers in Human Behavior, 41, 104-111.

Lou, L. L., Yan, Z., Nickerson, A., \& McMorris, R. (2012). An examination of the reciprocal relationship of loneliness and Facebook use among first-year college students. Journal of Educational Computing Research, 46(1), 105-117.

Lüders, M. (2008). Conceptualizing personal media. New Media \& Society, 10(5), 683-702.

Ma, M. L. Y., \& Leung, L. (2006). Unwillingness-to-communicate, perceptions of the Internet and self-disclosure in ICQ. Telematics and Informatics, 23(1), 22-37.

McCown, J. A., Fischer, D., Page, R., \& Homant, M. (2001). Internet relationships: People who meet people. CyberPsychology \& Behavior, 4(5), 593-596.

McKenna, K. Y., Green, A. S., \& Gleason, M. E. (2002). Relationship formation on the Internet: What's the big attraction?. Journal of social issues, 58(1), 9-31.

Muscanell, N. L., \& Guadagno, R. E. (2012). Make new friends or keep the old: Gender and personality differences in social networking use. Computers in Human Behavior, 28(1), 107-112.

Oldenburg, R., \& Brissett, D. (1982). The third place. Qualitative sociology, 5(4), 265-284.

Ong, C. S., Chang, S. C., \& Wang, C. C. (2011). Comparative loneliness of users versus nonusers of online chatting. Cyberpsychology, Behavior, and Social Networking, 14(1-2), 35-40.

Park, N., Chung, J. E., \& Lee, S. (2012). Explaining the use of text-based communication media: An examination of three theories of media use. Cyberpsychology, Behavior, and Social Networking, 15(7), 357-363.

Park, N., Kee, K. F., \& Valenzuela, S. (2009). Being immersed in social networking environment: Facebook groups, uses and gratifications, and social outcomes. CyberPsychology \& Behavior, 12(6), 729-733.

Parks, M. R., \& Floyd, K. (1996). Making friends in cyberspace. Journal of ComputerMediated Communication, 1(4).

Pénard, T., \& Poussing, N. (2010). Internet use and social capital: The strength of virtual ties. Journal of Economic Issues, 44(3), 569-595.

Peris, R., Gimeno, M. A., Pinazo, D., Ortet, G., Carrero, V., Sanchiz, M., \& Ibanez, I. (2002). Online chat rooms: Virtual spaces of interaction for socially oriented people. CyberPsychology \& Behavior, 5(1), 43-51. 
Petrič, G., Petrovčič, A., \& Vehovar, V. (2011). Social uses of interpersonal communication technologies in a complex media environment. European Journal of Communication, 26(2), 116-132.

Petrović D. (2013). The Internet as Interpersonal Media - Case of Serbia. Sociologija, 55, 417-438. (in Serbian).

Petrović D. (2012). New forms of social networking: the internet's role in establishing interpersonal relationships in Serbia. PhD Thesis, University of Belgrade. Serbia (in Serbian).

Petrović D. (2009). Personal networking function of the Internet. Sociologija, 51, 23 44. (in Serbian).

Pittman, M., \& Reich, B. (2016). Social media and loneliness: Why an Instagram picture may be worth more than a thousand Twitter words. Computers in Human Behavior, 62, 155-167.

Ploderer, B., Howard, S., \& Thomas, P. (2008). Being online, living offline: the influence of social ties over the appropriation of social network sites. In Proceedings of the 2008 ACM conference on Computer supported cooperative work (pp. 333-342). ACM.

Ploug, T. (2009). Ethics in cyberspace (pp. 3-12). Springer Netherlands.

Pollet, T. V., Roberts, S. G., \& Dunbar, R. I. (2011). Use of social network sites and instant messaging does not lead to increased offline social network size, or to emotionally closer relationships with offline network members. Cyberpsychology, Behavior, and Social Networking, 14(4), 253-258.

Ramirez, A., \& Broneck, K. (2009). IM me': Instant messaging as relational maintenance and everyday communication. Journal of Social and Personal Relationships, 26(2-3), 291-314.

Rapee, R. M., \& Heimberg, R. G. (1997). A cognitive-behavioral model of anxiety in social phobia. Behaviour research and therapy, 35(8), 741-756.

Ross, C., Orr, E. S., Sisic, M., Arseneault, J. M., Simmering, M. G., \& Orr, R. R. (2009). Personality and motivations associated with Facebook use. Computers in human behavior, 25(2), 578-586.

Russell, D., Peplau, L. A., \& Ferguson, M. L. (1978). Developing a measure of loneliness. Journal of personality assessment, 42(3), 290-294.

Schermelleh-Engel, K., Moosbrugger, H., \& Müller, H. (2003). Evaluating the fit of structural equation models: Tests of significance and descriptive goodness-of-fit measures. Methods of psychological research online, 8(2), 23-74.

Shalom, J. G., Israeli, H., Markovitzky, O., \& Lipsitz, J. D. (2015). Social anxiety and physiological arousal during computer mediated vs. face to face communication. Computers in Human Behavior, 44, 202-208.

Sheldon, P. (2008). Student favorite: Facebook and motives for its use. Southwestern Mass Communication Journal, 23(2), 39-53.

Soukup, C. (2006). Computer-mediated communication as a virtual third place: building Oldenburg's great good places on the world wide web. New Media \& Society, 8(3), 421-440. 
Stepanikova, I., Nie, N. H., \& He, X. (2010). Time on the Internet at home, loneliness, and life satisfaction: Evidence from panel time-diary data. Computers in Human Behavior, 26(3), 329-338.

Tabachnick BG, Fidell LS. (2007) Using Multivariate Statistics. Boston: Pearson Education Inc.

Tobin, S. J., Vanman, E. J., Verreynne, M., \& Saeri, A. K. (2015). Threats to belonging on Facebook: Lurking and ostracism. Social Influence, 10(1), 31-42.

Valkenburg, P. M., \& Peter, J. (2007a). Online communication and adolescent wellbeing: Testing the stimulation versus the displacement hypothesis. Journal of Computer-Mediated Communication, 12(4), 1169-1182.

Valkenburg, P. M., \& Peter, J. (2007b). Preadolescents' and adolescents' online communication and their closeness to friends. Developmental psychology, 43(2), 267-277

van den Eijnden, R. J., Meerkerk, G. J., Vermulst, A. A., Spijkerman, R., \& Engels, R. C. (2008). Online communication, compulsive Internet use, and psychosocial well-being among adolescents: a longitudinal study. Developmental psychology, 44(3), 655.

Van den Heuvel, A., van den Eijnden, R. J., van Rooij, A. J., \& van de Mheen, D. (2012). Meeting online contacts in real life among adolescents: The predictive role of psychosocial wellbeing and internet-specific parenting. Computers in Human Behavior, 28(2), 465-472.

Van Zalk, M. H., Branje, S. J., Denissen, J., Van Aken, M. A., \& Meeus, W. H. (2011). Who benefits from chatting, and why? The roles of extraversion and supportiveness in online chatting and emotional adjustment. Personality and Social Psychology Bulletin, 37(9), 1202-1215.

Vergeer, M., \& Pelzer, B. (2009). Consequences of media and Internet use for offline and online network capital and well-being. A causal model approach. Journal of Computer-Mediated Communication, 15(1), 189-210.

Vitak, J., Ellison, N. B., \& Steinfield, C. (2011). The ties that bond: Re-examining the relationship between Facebook use and bonding social capital. In System Sciences (HICSS), 2011 44th Hawaii International Conference on (pp. 1-10). IEEE.

Wang, J. L., Jackson, L. A., \& Zhang, D. J. (2011). The mediator role of selfdisclosure and moderator roles of gender and social anxiety in the relationship between Chinese adolescents' online communication and their real-world social relationships. Computers in Human Behavior, 27(6), 2161-2168.

Weidman, A. C., Fernandez, K. C., Levinson, C. A., Augustine, A. A., Larsen, R. J., \& Rodebaugh, T. L. (2012). Compensatory internet use among individuals higher in social anxiety and its implications for well-being. Personality and individual differences, 53(3), 191-195.

Weiss, R.S. (1974). The Provisions of Social Relationships, in Z. Rubin (ed.), Doing Unto Others. Englewood Cliffs, NJ, Prentice-Hall, 17-26.

Yen, J. Y., Yen, C. F., Chen, C. S., Wang, P. W., Chang, Y. H., \& Ko, C. H. (2012). Social anxiety in online and real-life interaction and their associated factors. Cyberpsychology, Behavior, and Social Networking, 15(1), 7-12. 
Zhang, S., Jiang, H., \& Carroll, J. M. (2010). Social identity in Facebook community life. International Journal of Virtual Communities and Social Networking, 2(4), $66-78$

Zhao, S. (2006). Do Internet users have more social ties? A call for differentiated analyses of Internet use. Journal of Computer-Mediated Communication, 11(3), 844-862.

\section{Kakva je naša onlajn interakcija? \\ Jedan pristup za proučavanje multidimenzionalnosti onlajn komunikacije}

\section{Dalibor Petrović}

Saobraćajni fakultet, Univerzitet u Beogradu

\section{Miloš Bešić}

Fakultet političkih nauka, Univerzitet u Beogradu

\section{Marijana Petrović \\ Saobraćajni fakultet, Univerzitet u Beogradu}

Ukoliko se ne vodi računa o različitim dimenzijama onlajn interakcije lako se može desiti da zbog njihovog međusobnog preklapanja i maskiranja dođemo do sasvim pogrešnih istraživačkih nalaza. U skladu sa razumevanjem onlajn interakcije kao multidimenzionalnog procesa izdvojili smo dva suštinski različita tipa onlajn komunikacije - prokreativni i transmisioni. Onlajn komunikaciju prokreativnog tipa razumemo kao tendenciju pojedinca ka upotrebi interneta kao prostora za društvenu interakciju nasuprot suštinski različitog transmisionog tipa onlajn interakcije koja se zasniva na kanalskoj, jedan na jedan komunikaciji, međusobno poznatih subjekata. Cilj ovog rada je da se bolje istraže različite dimenzije onlajn prokreativnosti. Na osnovu našeg teorijskog polazišta identifikovali smo tri dimenzije prokreativnosti i razvili skalu onlajn prokreativnosti (OPS-Online Procreativity Scale) za njihovo merenje. Validnost OPS je verifikovana posredstvom EFA i CFA čime je potvrđena trodimenzionalna struktura skale. Koristeći OLS regresionu analizu utvrdili smo da pol, psihološke karakteristike i upotreba platformi za društveno umrežavanje, imaju različit uticaj na tri dimenzije prokreativnosti. Utvrdili smo da su pol, veličina mesta boravka, udeo nepoznatih ljudi među prijateljima na onlajn mrežama i usamljenost prediktori spremnosti da se uđe u interakciju sa nepoznatim ljudima na internetu, dok je vreme koje se provodi na onlajn mrežama jedino bilo prediktor tendencije da se učestvuje u javnoj onlajn interakciji.

Ključne reči: dimenzije onlajn komunikacije, prokreativnost, skala onlajn prokreativnosti, prediktori 


\section{Appendix 1. \\ Online Procreativity Scale}

Read each of the following statements carefully and indicate how often you participate in listed activities when online:
1. Never
2. Once a year or less
3. Few times per year
4. Few times per month
5. Once to twice a week
6. Few times a week
7. Everyday

1. I accept friend requests from unknown people on social network sites

2. I post on web forums, blogs, online games

3. I chat with strangers online

4. I send friend requests to unknown people on social network sites

5. I read other people's discussions on web forums, blogs, online games

6. I post personal photos on social network sites

7. I participate in discussions on web forums, blogs, online games

8. When I am online I socialize with people that I have never met in person

9. I hang out with people online

10. I make comments on my friends' statuses, photos and comments on social network sites 